\title{
MECP2 wt Allele
}

National Cancer Institute

\section{Source}

National Cancer Institute. MECP2 wt Allele. NCI Thesaurus. Code C75728.

Human MECP2 wild-type allele is located in the vicinity of Xq28 and is approximately $76 \mathrm{~kb}$ in length. This allele, which encodes methyl-CpG-binding protein 2 , is involved in transcriptional modulation. Mutations in the gene are associated with a number of congenital neurological diseases. 